\title{
Study on the Influence Law of Various Factors on Volcanic Autoclaved Aerated Concrete
}

\author{
Xinghua $\mathrm{Fu}^{1, *}$, Wenhong $\mathrm{Tao}^{1}$, Shuangshuang $\mathrm{Hou}^{2}$ \\ 1School of Materials Science and Engineering \\ University of Jinan \\ Shandong, China \\ e-mail: mse_fuxh@ujn.edu.cn
}

\author{
Huaizhuo Zhang ${ }^{1,2}$ \\ 2GCBM Technology Center \\ Shenzhen Gangchuang Building Material CO, LTD \\ Shenzhen, China \\ e-mail: 923042563@qq.com
}

\begin{abstract}
With the shortage of fly ash in south of China and rush towards sustainability, how to use of resources of volcanic powder has become a new field for experts and scholars. This paper aims to study the suitability of replacing cement by volcanics in producing autoclaved aerated concrete (AAC) and find out the influencing rule of water cement ratio, aluminum powder content, cement content and the fineness of volcanic powder. Scanning electron microscopy (SEM) investigations of the microstructure and hydration products in the autoclaved aerated concrete (AAC) provide new insights.
\end{abstract}

Keywords-autoclaved aerated concrete; volcanic powder; dry density; water absorption rate; compressive Strength

\section{INTRODUCTION}

Autoclaved aerated concrete (AAC) has a long history of 90 years in commercial production. It has shown many advantages in terms of light weight, high strength, low thermal conductivity and good fire resistance[1,2]. In general, $\mathrm{AAC}$ is a kind of the porous silicate material. The raw materials are cement, gypsum, lime, metallic Al powder and quartz sand. These materials are mixed with water, molded and turned to be porous mixture at atmospheric pressure by the addition of gas-generating agents (Al powder). Then, the mass is cured at $200^{\circ} \mathrm{C}$ using saturated steam for several hours[3], silicates reacts with $\mathrm{CaO}$ to form calcium silicate hydrate (CSH).

Volcanics is formed during volcanic eruptions, it is rich in resources. Volcanic powder is a kind of industrial waste residue, which can cause serious pollution. Developing volcanic powder can reduce energy consumption and waste of resources. This step will make it possible to develop materials available locally and will contribute to the social development of the area.

Fly ash is the traditional raw materials for autoclaved aerated concrete. The experiment used volcanic powder substitute for fly ash to produce autoclaved aerated concrete (AAC) in this paper and find out the influencing rule of water cement ratio , aluminum powder content, cement content and the fineness of volcanic powder.

\section{RAW MATERIAL}

\section{A. Volcanic Powder}

In this study, the volcanic rock was supplied by hainan, China. There are three different fineness of volcanic powder.
Volcanic rock ground to 20,25 and 30 minutes in a laboratory ball milland and dried at a temperature of $105^{\circ} \mathrm{C}$ to eliminate free water. The density and specific surface area were measured by Lee pycnomete and Blaine permeability apparatus. Determined fineness by negative pressure sieve method. The relationship between grinding time and powder properties are shown in Table 1. With the increasing of grinding time,the specific surface area increases and sieve residue percentage decreases. The results show that the fineness of the volcanic rock powder becomes fine.

The chemical composition of the volcanics indicates a salic mineral (Table 2). volcanic powder's chemical composition is mainly $\mathrm{SiO} 2$ and $\mathrm{A} 12 \mathrm{O} 3$, this two kinds of minerals in which are about $65 \%$ or more, and chemical composition is good. Volcanic powder would react with calcium hydroxide to form more calcium silicate hydrate. Autoclaved aerated concrete (AAC) which contain volcanic powder would exhibit considerable enhancement in durability properties.

TABLE I. THE RELATIONSHIP BETWEEN GRINDING TIME AND PROPERTIES OF VOLCANIC POWDER

\begin{tabular}{|c|c|c|c|}
\hline $\begin{array}{c}\text { Types of } \\
\text { materials }\end{array}$ & $\begin{array}{c}\text { Density } \\
\left(\mathbf{g} / \mathbf{c m}^{\mathbf{3}}\right)\end{array}$ & $\begin{array}{c}\text { specific surface } \\
\text { area }\left(\mathbf{m}^{\mathbf{2}} \mathbf{/ K g}\right)\end{array}$ & $\begin{array}{c}\text { Sieve residue } \\
\text { percentage } \mathbf{( \% )}\end{array}$ \\
\hline $20 \mathrm{~min}$ & 2.868 & 463.6 & 3.36 \\
\hline $25 \mathrm{~min}$ & 2.868 & 499.8 & 2.88 \\
\hline $30 \mathrm{~min}$ & 2.868 & 517.1 & 2.68 \\
\hline
\end{tabular}

Particle size distribution is an important physical indexes of volcanic powder. The particle size distribution of raw materials have a great influence on the performance of concrete, the three different kinds of volcanic powder fineness were detected by laser particle size analyzer. The results of the particle size distribution are shown in Figure 1, Figure 2 and Figure 3. The average particle size (mean) and median diameter (average) of each fineness were gradually decreased with the increasing of grinding time. Moreover,some difficult ground minerals show independent distribution peaks in the coarse particles.

TABLE II. CHEMICAL COMPOSITION OF VOLCANIC POWDER (WT\%)

\begin{tabular}{|l|c|c|c|c|c|c|}
\hline $\mathbf{S i O}_{2}$ & $\mathbf{A l}_{2} \mathbf{O}_{\mathbf{3}}$ & $\mathbf{C a O}$ & $\mathbf{M g O}$ & $\mathbf{F e}_{2} \mathbf{O}_{3}$ & $\mathbf{N a}_{2} \mathbf{O}$ & $\mathbf{K}_{\mathbf{2}} \mathbf{O}$ \\
\hline 50.43 & 16.36 & 8.95 & 4.44 & 9.95 & 4.58 & 1.72 \\
\hline
\end{tabular}




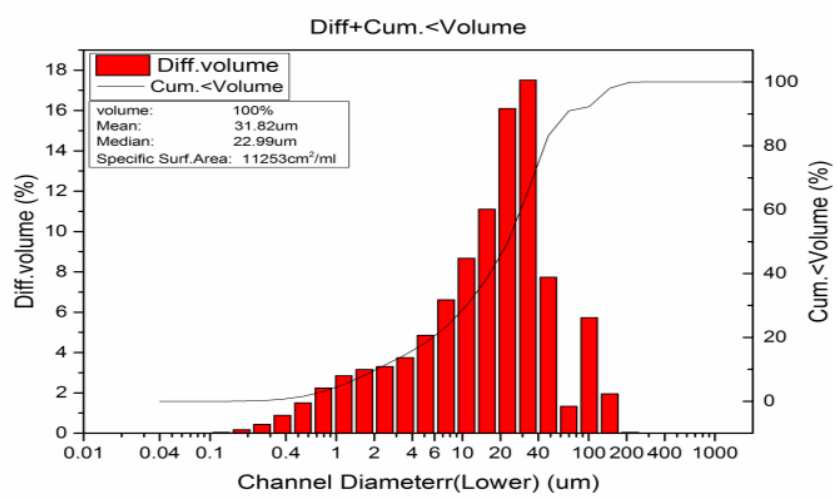

Figure 1. Laser particle size distribution of volcanics $20 \mathrm{~min}$ volcanic powder.

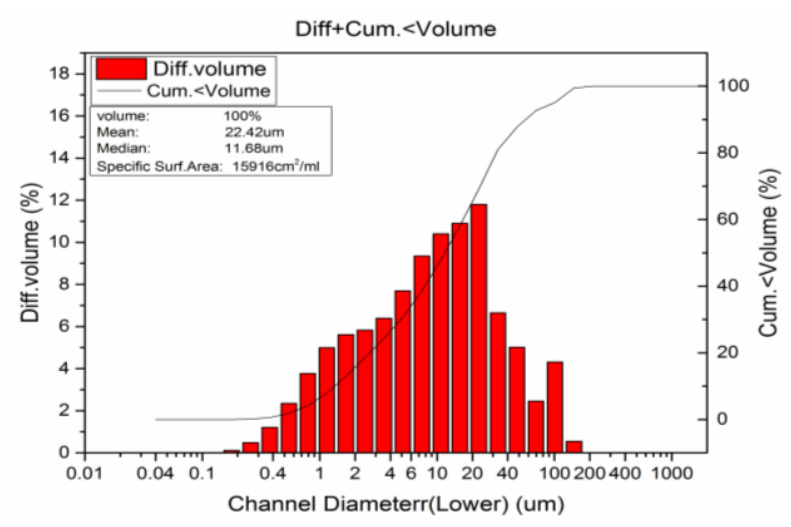

Figure 2. Laser particle size distribution of volcanics 25 min volcanic powder.

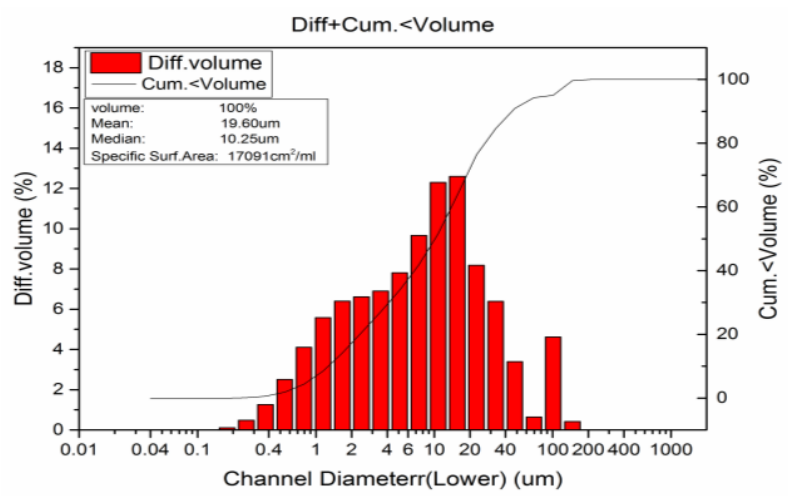

Figure 3. Laser particle size distribution of volcanics $30 \mathrm{~min}$ volcanic powder.

\section{B. Other Materials}

In this study, the type of Portland cement is P.O 42.5 and which was supplied by Shandong ceme supplier. Performance indexes of cement shown in the Table 3. Through the chemical composition of the lime (Table 4), the effective $\mathrm{CaO}$ content of the lime used in this experiment is more than $90 \%$. The chemical composition of desulfurization gypsum is shown in Table 5. The main components of the air lead agent used are resin thermal polymer.
TABLE III. PerformanCE INDEXES OF CEMENT

\begin{tabular}{|c|c|c|c|c|c|}
\hline \multicolumn{2}{|c|}{ setting time(min) } & \multicolumn{2}{c|}{$\begin{array}{c}\text { Compressive } \\
\text { strength(MPa) }\end{array}$} & \multicolumn{2}{c|}{$\begin{array}{c}\text { Bending } \\
\text { strength(MPa) }\end{array}$} \\
\hline Initial setting & final setting & $7 \boldsymbol{d}$ & $\mathbf{2 8 d}$ & $7 \boldsymbol{d}$ & $\mathbf{2 8 d}$ \\
\hline 180 & 270 & 34 & 51 & 6.93 & 8.63 \\
\hline
\end{tabular}

TABLE IV. CHEMICAL COMPOSITION OF RAW LIME (WT\%)

\begin{tabular}{|c|c|c|c|c|c|}
\hline $\mathbf{C a O}$ & $\mathbf{M g O}$ & $\mathbf{S i O}_{\mathbf{2}}$ & $\mathbf{F e}_{\mathbf{2}} \mathbf{O}_{\mathbf{3}}$ & $\mathbf{A l}_{\mathbf{2}} \mathbf{O}_{\mathbf{3}}$ & $\mathbf{S O}_{\mathbf{3}}$ \\
\hline 95.17 & 2.36 & 1.02 & 0.44 & 0.63 & 0.21 \\
\hline
\end{tabular}

TABLE V. CHEMICAL COMPOSITION OF DESULFURIZATION GYPSUM (WT\%)

\begin{tabular}{|c|c|c|c|c|c|c|}
\hline $\mathbf{S i O}_{2}$ & $\mathrm{Al}_{\mathbf{2}} \mathbf{O}_{\mathbf{3}}$ & $\mathbf{F e}_{2} \mathbf{O}_{3}$ & $\mathbf{C a O}$ & $\mathbf{M g O}$ & $\mathbf{S O}_{3}$ & Loss \\
\hline 1.48 & 1.01 & 1.0 & 31.51 & 1.82 & 41.38 & 21.62 \\
\hline
\end{tabular}

\section{TEST SCHEME AND RESULTS}

Using water cement ratio, aluminum powder content, cement content and the fineness of volcanic powder as variable,content of cement and volcanic powder is $80 \%$. The study used $15 \mathrm{wt} \%$ of lime, $5 \mathrm{wt} \%$ of gypsum , $0.2 \%$ of air entrained agent and dried at $4 \mathrm{~h}$ for $60^{\circ} \mathrm{C}$. specimens curied at $1 \mathrm{Mpa}$ for $8 \mathrm{~h}$ in autoclave. Test results are shown in Table 6.

\section{A. Effect of Various Factors on Dry Density}

From the Figure 4, we know that Effect of various factors on dry density: water cement ratio>aluminum powder>cement content>grinding time. Dry density will decrease along with the increase of water cement ratio and aluminum powder. Increase of water cement ratio make dynamic viscosity of slurry decrease. Bubble meet resistance from slurry was decrease and the block get good pore structure [4], the dry density of aerated concrete was decrease. The more holes aerated concrete had, the smaller the dry density was. And hydrogen produced by aluminum powder forms hole in aerated concrete. With the increase of aluminum powder, bubble increases obviously. Thus dry density was decrease. With the increase of cement, dry density radio increases initially and decreases afterwards. The dry density of aerated concrete which had different content of cement is different. Grinding time has little effect on dry density, with the increase of grinding time, dry density decreases. From the data from Figure 4, when water cement ratio is 0.425 , the aluminum powder content is $0.10 \%$, the cement content is $18 \%$, the grinding time is 20 minutes, and the dry density of the block is high.

\section{B. Effect of Various Factors on Water Absorption rate}

As Figure 5 shows, affection of various factors on water absorption rate: aluminum powder $>$ water cement ratio>cement content>grinding time. water absorption rate will increase along with the increase of aluminum powder and cement. With the increase of water cement ratio, water absorption rate increases initially and decreases afterwards. Increase of grinding time makes water absorption rate decrease. When the water cement ratio is 0.425 , the 
aluminum powder content is $0.10 \%$, the cement content is $18 \%$, the grinding time is 30 minutes, and the water absorption of the block is low.

\section{Effect of Various Factors on Compressive Strength}

As Figure 6 shows, affection of various factors on compressive Strength : grinding time >cement content $>$ water cement ratio>aluminum powder. With the increase of water cement ratio, compressive Strength decreases. When the water cement ratio is high, the concentration of cementations' materials is low. The excess water in the concrete will form connected pores. And increase of porosity decreases the strength. With the increase of aluminum powder, compressive Strength increases initially and decreases afterwards. The effect of grinding time on compressive strength is similar to aluminum powder. With the increase of grinding time, the volcanic powder had good filling effect, but excessive grinding will reduce the strength. The hydration calcium silicate is beneficial to the compressive strength, increase cement will increase the compressive strength. When the water cement ratio is 0.425 , the aluminum powder content is $0.125 \%$, the cement content is $23 \%$, the grinding time is 25 minutes, the compressive strength is great.

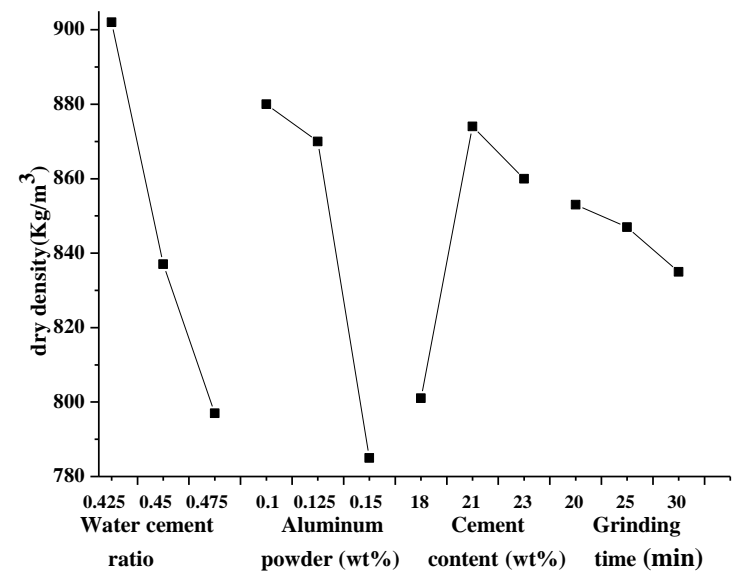

Figure 4. Effect of various factors on dry density.

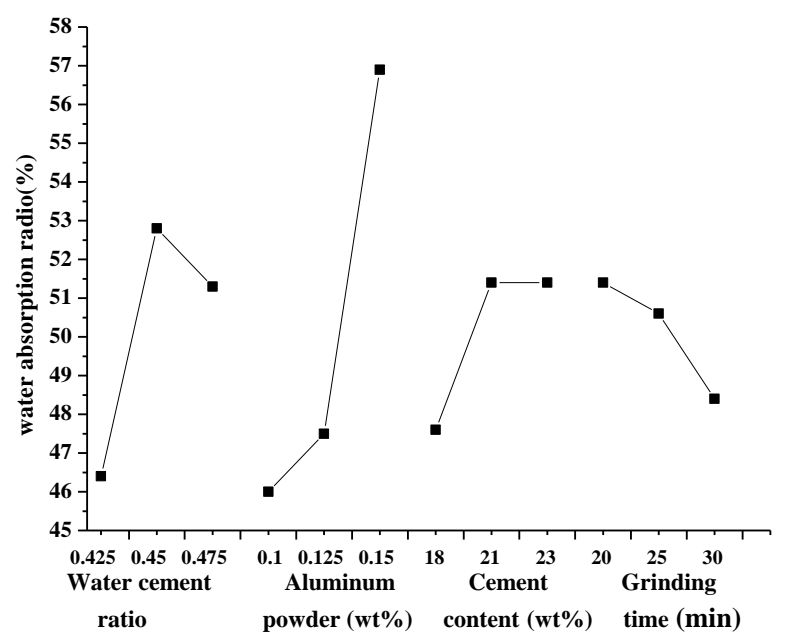

Figure 5. Effect of various factors on water absorption rate.

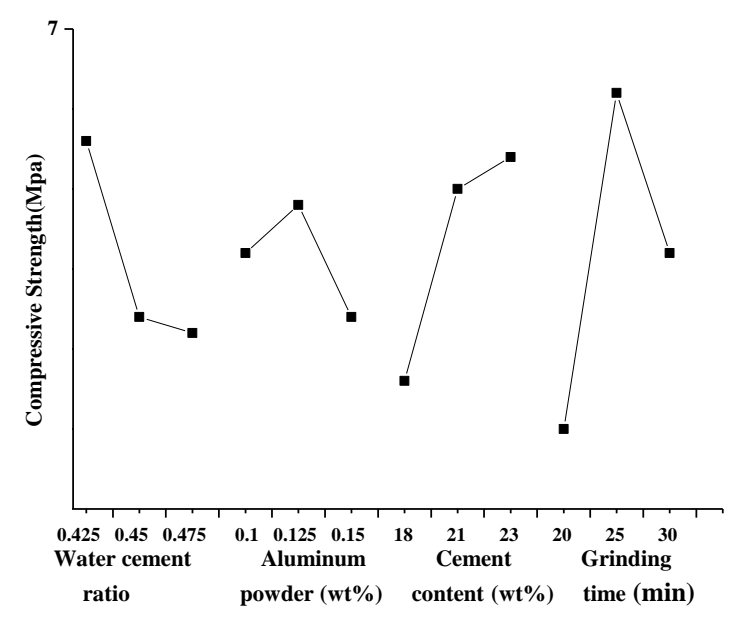

Figure 6. Effect of various factors on compressive strength.

\section{SEM ANALYSIS}

The content and type of the pores and hydration products in the autoclaved aerated concrete have great influence on the mechanical properties, water absorption ratio and dry density. In this study, the surface morphology of aerated concrete hydration products was observed by SEM scanning electron microscope, and analyzed the extent of hydration. Test results are shown in Figure 7.

1 shows the whole panorama of the holes in the autoclaved aerated concrete. The pores of block is uniform distribution. 2 shown hydration products in pores after autoclaving. The structure of hydration was compact. The main hydration production are $\mathrm{C}-\mathrm{S}-\mathrm{H}$ gel and tobermorite crystals. In the left of 3 is the hydration product in pores, which is C-S-H gel. It is the hydration product of cement. Micropores can hold water in which silica can be dissolved and diffused. And extent of hydration is good. The right of 3 , 4 shows acicular and threadiness tobermorite in the autoclaved aerated concrete.

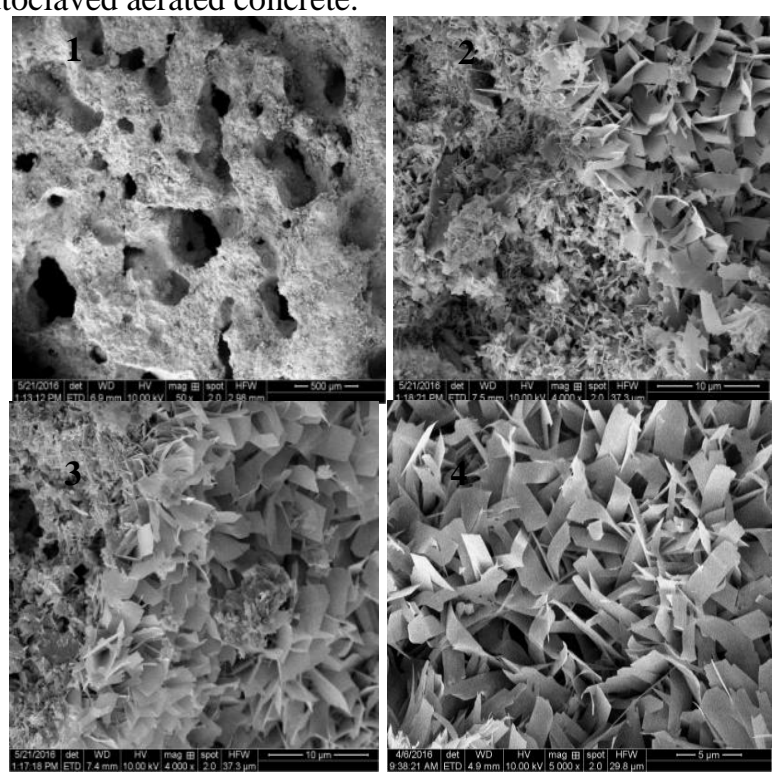

Figure 7. Microstructure of aerated concrete. 


\section{CONCLUSIONS}

In this study, It is feasible to use volcanic powder instead of cement to produce autoclaved aerated concrete. Through analysis the test result, in a certain range, water cement ratio, aluminum powder content, cement content and grinding time has varying degrees influence on Autoclaved aerated concrete. Water cement ratio and aluminum powder content have a great influence on dry density and water absorption,the compressive strength depends on the grinding time and cement content. The main hydration production of autoclaved aerated concrete is $\mathrm{C}-\mathrm{S}-\mathrm{H}$ gel and tobermorite crystals. The structure of hydration in pores was compact after autoclaving.

\section{REFERENCES}

[1] Narayanan, N., and K. Ramamurthy. "Structure and properties of aerated concrete: a review." Cement \& Concrete Composites 22.5(2000):321-329.

[2] C. Straub, M.V.A. Florea, H.J.H. Brouwers, "Autoclaved aerated concrete - mixparameters and their influence on final properties." International Baustofftagung(2015) :2822-2829.

[3] Hauser, A., and U. Eggenberger. "Fly ash from cellulose industry as secondary raw material in autoclaved aerated concrete." Cement \& Concrete Research 29.3(1999):297-302.

[4] Jie Yang, "The influence of several main factors on the performance of the steam aerated concrete. "New building materials(2012):70-73.

TABLE VI. THE TEST RESULTS

\begin{tabular}{|c|c|c|c|c|c|c|c|}
\hline Number & $\begin{array}{c}\text { Water cement } \\
\text { ratio }\end{array}$ & $\begin{array}{c}\text { Aluminum } \\
\text { powder }(w t \%)\end{array}$ & Cement (wt\%) & $\begin{array}{c}\text { Grinding time } \\
\text { (min) }\end{array}$ & $\begin{array}{c}\text { Dry density } \\
\text { (Kg/m3) }\end{array}$ & $\begin{array}{c}\text { Water } \\
\text { absorption } \\
\text { rate }(\%)\end{array}$ & $\begin{array}{c}\text { Compressive } \\
\text { strength } \\
\text { (Мpa) }\end{array}$ \\
\hline A1 & 0.425 & 0.15 & 18 & 30 & 861 & 48.9 & 5.2 \\
\hline A2 & 0.425 & 0.125 & 21 & 25 & 885 & 45.5 & 7.7 \\
\hline A3 & 0.425 & 0.1 & 23 & 20 & 960 & 44.8 & 6.0 \\
\hline A4 & 0.45 & 0.15 & 21 & 20 & 740 & 62.1 & 3.8 \\
\hline A5 & 0.45 & 0.125 & 23 & 30 & 867 & 49.7 & 6.3 \\
\hline A6 & 0.45 & 0.1 & 18 & 25 & 903 & 46.6 & 5.6 \\
\hline A7 & 0.475 & 0.15 & 23 & 25 & 753 & 59.8 & 6.5 \\
\hline A8 & 0.475 & 0.125 & 18 & 20 & 859 & 47.4 & 3.6 \\
\hline A9 & 0.475 & 0.1 & 21 & 30 & 778 & 46.6 & 5.3 \\
\hline
\end{tabular}

